\title{
Bodrum Yarımadası ve Zeytinyağı Turizmi: Uygulanabilirliği Açısından Swot Analizi ile Değerlendirilmesi
}

Duran Cankül ${ }^{1}$

Efnan Ezenel ${ }^{2}$

Bodrum Yarımadası ve Zeytinyağı Turizmi: Uygulanabilirliği Açısından Swot Analizi ile Değerlendirilmesi

Öz

Bu araştırma Bodrum yarımadasının zeytinyağı turizmi potansiyelinin ortaya çıkarılmasını amaçlamaktadır. Bu amaç doğrultusunda Bodrum yarımadasında zeytinyağı turizminin uygulanabilirliği SWOT analizi ile değerlendirilmiştir. Araştırma nitel bir çalışmadır. Araştırmanın örneklemi olasılık dışı örnekleme türlerinden amaçlı örnekleme yöntemine göre belirlenmiştir. Bu kapsamda araştırmanın örneklemini Bodrum yarımadasında yaşayan konu ile ilgili doğrudan veya dolaylı olarak etkisi olan bölge sakini, kamu, STK, üniversite ve turizm işletmelerinin sahipleri yöneticisi veya çalışanları oluşturmaktadır. Araştırmada veri toplama tekniği olarak, yarı yapılandırılmış sözlü görüşme tekniği kullanılmıştır. Alan araştırması, 2018 yılı Ocak ayı ile Şubat ayı arasında, ilgili paydaşlarla yüz yüze görüşülerek gerçekleştirilmiştir. SWOT analizi neticesinde elde edilen veriler, bölge için tehdit edici unsurların ve bölgenin zayıf yönleri olduğunu gösterse de doğru uygulamalar sonucu zeytinyağı turizminin Bodrum yarımadası için uygun bir turizm etkinliği olabileceğini ortaya koymaktadır.

Anahtar Kelimeler: Zeytinyağı Turizmi, Bodrum Yarımadası, Swot Analizi

\begin{abstract}
Bodrum Peninsula and Olive Oil Tourism: A Swot Analysis on its Feasibility

Abstract

This study aims to discover the olive oil tourism potential of Bodrum peninsula. In this terms, the feasibility of olive oil tourism in Bodrum is analysed by a swot analysis based on a qualitative perspective. The sample of the study was determined by the purposive sampling which is non-probability sampling technique. In this context, the sample of the study consists of residents of Bodrum, owners, managers, employees of the tourism enterprises and affiliates in the public, NGOs and universities of the region. Data were collected by a semi-structured interview. Field research was conducted between January and February 2018 by interviewing the stakeholders face to face. The results of the swot analysis suggest that although there are both positive and negative aspects of the region, olive oil tourism could possibly be a proper activity for the peninsula if appropriate applications are performed.
\end{abstract}

Keywords: Olive oil Tourism, Bodrum Peninsula, Swot Analysis

\section{Giriş}

Gastronomi turizmi, özgünlük arayışı ile özdeşleşmiş turist türlerinin gittikçe artan arzularına yanıt vermek ve turistik destinasyonların rekabet gücünü tanımlamak açısından önemli turizm türlerinden biridir (Lopez-Guzman, Hernandez-Mogollon, Di-Clemente, 2014: 95) ve bir ülkenin, bölgenin veya yörenin yemeklerini deneyimlemek noktasında turistler için turizm deneyiminin hayati bir bileşeni olarak kabul edilmektedir (Pullphothong, ve Sopha, 2012). Gastronomi turizmi her geçen yıl hem bilimsel toplumda hem de turizm hizmetlerinin kullanıcıları arasında daha fazla dikkat çekmektedir (Drašković, 2016) ve yükselen turizm eğilimleri arasındadır. Günümüzde Akdeniz ülkeleri gastronomi turizmi kapsamında çeşitli yöresel ve doğal ürünleri turistik bir faaliyet çerçevesinde ziyaretçilere görsel, tadımsal ve rekratif bir şekilde sunmaktadır. Yörede turistik faaliyet gerçekleştiren ziyaretçiler aynı zamanda yörenin yerel mutfağını da de-

\footnotetext{
${ }^{1}$ Dr. Öğr. Üyesi., Eskişehir Osmangazi Üniversitesi, Turizm Fakültesi, Gastronomi ve Mutfak Sanatları Bölümü. dcankul@ogu.edu.tr, yazar ORCID bilgisi: https://orcid.org/0000-0001-5067-6904.

${ }^{2}$ Yüksek Lisans Öğrencisi, Eskişehir Osmangazi Üniversitesi, Sosyal Bilimler Enstitüsü, Turizm İşletmeciliği Bölümü. efnan_ezenel@hotmail.com, yazar ORCID bilgisi: https://orcid.org/0000-0002-7183-8375.
} 
neyerek seyahat motivasyonlarını arttırmaktadır. Yöresel lezzetlerin bu faaliyetlerde etkili olmasının yanı sıra gastronomik festivallerde ve şenliklerde de sunularak destinasyonun çekiciliğine katkıda bulunmaktadır. Artık özellikle turistik destinasyonlarda otantik seyahat hizmetleri sağlamak destinasyonun çekiciliğini artırmada bir önkoşul olmaktadır ve yükselen bölgesel turizmi geliştirme girişimleri için yöresel olarak üretilen yiyecek içeceklerden yararlanılmaktadır (Baltescu, 2016; Boyne, Hall ve Williams, 2003). Bu ürünlerden biride zeytin ve zeytinden elde edilen zeytinyağıdır. Türkiye İstatistik Kurumu ‘Bitkisel Üretim İstatistikleri Veri Tabanı’na göre 6.192.904 dekarlık alan kaplayan toplam 117.790.487 zeytin ağacının var olduğu bir ülke olan Türkiye'de yeni turistik ürün yaratmak için zeytinyağı turizmi de gastronomi turizmine düşen payı arttırıcı bir fırsat olarak görülmektedir (TUIK, 2016).

Zeytinyağı turizmi birçok turizm çeşidi ile etkileşim içerisindedir. Bu etkileşim hem üretimi artırıcı etkiye sahip olabilmekte hem de yerel kalkınmaya katkı sağlayabilmektedir (LópezGuzmán, Morales, Cuadra ve Agüera, 2016). Agro turizm, eko turizm, kırsal turizm, endüstriyel miras turizmi, sürdürülebilir turizm ile iç içe olan zeytinyağı turizminin bir yöreye katacă̆ı fayda hem tarımsal hem ekonomik hem de turistiktir. Bu bağlamda bir kültür ürünü olan zeytinin tarımsal olarak değerlendirilmesinin yanı sıra Türkiye'de de turizm açısından değerlendirilebilecek yeni bir turistik ürün olabilme potansiyeline sahiptir. Bu çerçevede bu çalışma da Bodrum yarımadasının zeytinyağı turizmi potansiyelinin ortaya çıkarılması açısından oldukça önem taşımaktadır.

\section{Kavramsal Çerçeve}

\subsection{Zeytinyağı Turizmi ve Zeytinyağı Turisti}

Mevcut literatürde zeytinyağı turizmi ile ilgili tanıma belli ölçülerde rastlanmaktadır. Daha çok yabancı literatürde özellikle söz konusu turizm çeşidinin liderliğini yapan İspanya ve İtalya' da zeytinyağı turizminin birçok tanımına ve zeytinyağı turizmi rotalarına rastlanmaktadır. Örneğin oleo turizm, diğer adıyla zeytinyağı turizmi; yiyecek, meyve bahçelerine entegre edilmiş tipik mimaride konaklama, güzellik ve sağlık uygulamaları, rahatlama vb. zeytinyağı ile bağlantılı bilgileri içermektedir ve zeytinin dünyasını kuşatan kültürün özünü sağlayan gastronomi turizmi ile ilgili (özellikle kırsal alanlarda) bir iç turizm şekli olarak tanımlanmaktadır (Millán, Arjona ve Amador, 2014). Bir başka ifade ile zeytin turizmi kavramı kullanılarak kültürel mirasın korunmasına ve toplumsal kalkınmaya katkıda bulunan zeytin ve zeytinyağı dünyası ile ilgili bir turizm türü olarak tanımlanmaktadır (Morales, López-Guzmán, Cuadra ve Agüera, 2015). Bununla birlikte yerel bir tarım ürünü olarak görülen zeytinyağı kırsal turizmin kalkınması için turiste doğrudan satış sağlayan yeni bir ticari kanal olarak da ifade edilmektedir (Campón-Cerro, Folgado-Fernández ve Hernández-Mogollón, 2017). Ayrıca şarap turizmi gibi zeytinyağı turizmi de turizmin yeni yöntemleri olarak tarımı tamamlayıcı faaliyetler şeklinde kanalize edilerek birçok çiftçi ve aile için ek bir geçim kaynağı olarak vurgulanmaktadır ve bu faaliyetler kırsal alanlarda yeni bir büyüme umudu olarak görülmektedir (Torre, Morales ve Agudo, 2010).

Zeytinyağı turizmi yapılan bölgelerde yerel yönetimleri ve üreticileri teşvik etmenin önemli olduğu kadar ekonomik canlılığı sağlamak için ziyaretçilerin motivasyonunu arttıracak aktiviteler planlamak ve koordine etmekte son derece önemli rol oynamaktadır. Kırsal ve tarımsal bölgelerde gerçekleşen zeytinyağı turizmi diğer turizm türleri gibi birçok farklı aktivite olanağı da sunabilmektedir. Bu aktivitelerden yararlanan turistler ise zeytinyağı turisti olarak nitelendiril-

mektedir. Buna göre zeytinyağı turisti şu şekilde tanımlanmaktadır: bazı tatil günlerini zeytin ve 
zeytinyağının altında yatan kültürü daha derinlemesine çalışmak için belirli bir yerde vakit geçirmeksizin alışılmış ikamet yerine başka bir destinasyonu tercih eden ve aşağıdaki aktivitelerde yer alan insanlardır (Torre, Fuentes ve Hidalgo, 2017).

$>$ Zeytin sıkma atölyelerine, eski zeytin değirmenlerine, zeytin tarlalarındaki eski malikanelere, zeytin mahzenleri (oleoteca), zeytinyağına özel marketler ya da zeytinyağı müzelerine ziyaretler. Bu şekilde zeytinyağı üretimi arkasındaki özel süreç hakkında bilgi edinmek mümkün olmaktadır.

$>$ Zeytin koruluklarına ziyaret ve zeytin koruluğu manzaralı estetik içsel dönüş, yoga etkinliklerine katılım. Bu bölümde, bin yıllık zeytin ağaçları ile içsel dönüş yapılmaktadır.

$>$ Belirli üretim yerlerinde yapılan zeytinyağı festivallerine katılım.

$>$ Zeytin ağaçlarının yetiştirilmesiyle bağlantılı farklı halk gelenekleri hakkında bilgi edinimi.

$>$ Zeytinyağının ana cazibe merkezi olduğu gastronomik etkinliklere katılım.

$>$ Zeytin ve zeytinyağı tasarımlı bağlantılı tur güzergahı.

$>$ Zeytinyağı ürünleri ile bağlantılı fuarlara katılım.

$>$ Zeytin ve zeytinyağı ile ilgili diğer sanayilerin özelliklerini öğrenmek (Kozmetik, konservecilik, oymacılık, zeytin terbiyelemek vb.).

\subsection{Zeytinyağı Turizmi ve Etkileşim İçerisindeki Turizm Türleri}

Zeytinyağı ile ilgili tanımlar doğrultusunda zeytinyağı turizmi tarım, ekoloji, kültürel miras, sürdürülebilirlik, ekonomi ile bir araya gelerek destinasyon çekim unsuru olarak önemli bir rol oynamaktadır. Kültürel, turistik ve gastronomik bir deneyim sunarak bir destinasyonun pazarlanmasına olanak sağlamaktadır. Turistik bir ürünün çeşitlendirilmesinde seyahat motivasyonu sağlayan bir turizm çeşidi olarak gerçekleştirilmektedir. Ek olarak zeytinyağı turizminin tanımına bakıldığında söz konusu kavramın diğer turizm türlerinin içinde farklılaştığı görülmektedir ve birçok turizm türü ile etkileşim halindedir.

Zeytinyağı turizmi agro turizm yani tarım turizmi ile ilişkilendirilerek veya yeni gelişen bir agro turizm faaliyeti olarak da ifade edilmektedir (Saltık ve Çeken, 2017). Agro turizm bir tarım arazisini ziyaret ederek ya da tarım kültürünün ve tarımsal işlerin yürütüldüğü bölgeleri seyahat, eğlence, eğitim ya da farklı aktivitelere dahil olarak gerçekleştirilen ve burada ziyaretçilere, üretenlere sunulan kaynağı koruyan, çevreye zarar vermeyen, yerel halk ve işletmelerin iç içe olduğu bir turizm türü olarak tanımlanmaktadır. Tanımlar doğrultusunda zeytin ve zeytinyağı tarımsal bir ürün olarak turizmde yer almaktadır. Turistik faaliyetler kapsamında zeytin ve zeytinyağı, zeytinden üretilen turistik ürünler, tadım aktiviteleri, zeytin ve zeytinyağı üretim atölyeleri, eğitimleri yer almaktadır. Bu faaliyetler tarım turizminin canlılığını arttırmakta, tarımsal üretimi desteklemekte ve yeni iş imkanları sunmaktadır. Bu durum tarım ve turizm sektörü arasındaki yoğun etkileşimi ve ilişkiyi göstermektedir. Tarım turizmi ile olan bu yoğun ilişki zeytin ve zeytinyağının kıymetli bir tarım ürünü (agri-food) olarak tarım turizmi literatüründe yer almasına olanak tanımaktadır. Bu bağlamda çalışmada da ele alınan zeytin, zeytinyağı gibi hem gastronomik hem tarımsal ürünlerin özel ilgi turizmi ve özellikle gastronomik turizm kaynağının temel bir unsuru olarak kabul edildiği belirtilmektedir (Kaufmann, Orphnidou ve Granau, 2012).

Zeytinyağı turizmi zeytinyağı ile ilgili belirli bir kültürü yansıtan kırsal alanlarda gelişmektedir. Kırsal turizm ise tarım alanına bağlıdır. Geliştiği bölgede yaşayanlar için gelir tahsis etmektedir ve bu alanlarda ekonominin dönüştürücü bir aracını oluşturmaktadır. Diğer bir ifade ile bölgenin ekonomik refahını sağlayan bir faktör haline gelmektedir (Agüera, Cuadra, López- 
Guzmán ve Morales, 2017; Millán, Agudo ve Agudo, 2010). Bu bağlamda kırsal alan kaynaklarının sürdürülebilirliğini göz ardı etmeden kırsal turizm için yeni faaliyetlerle kullanılması ziyaretçileri bu bölgeye çekmeye olanak tanımaktadır. Zeytinyağı turizmi de kırsal turizmin tarımsal aktivitelerinin içinde yer alarak ziyaretçilerin seyahatleri süresince bireysel deneyimlerine farklı bir motivasyon katmaktadır.

Zeytinyağı turizminin kırsal turizm ile ilişkisine ek olarak aslında eko turizmin ilkelerini de bir yandan gerçekleştirdiği görülmektedir. Zeytinyağı turizmi ile seyahat edenler eko turizm ilkeleri kapsamında her bir habitatın ekolojik dengedeki hayati rollerini benimsemekte, kültürel mirası korumakta, yerel halkın gelenek ve göreneklerine saygı göstermekte, yerel halkla karşılıklı bir etkileşimde bulunmakta ve yerel halka ek bir gelir sunmaktadır (Erdoğan, 2003). Tüm bu ilkeler sürdürülebilir turizm kavramı ile de birebir ilişkilendirilmesine neden olmakta ve sürdürülebilir kalkınmayı da içermektedir. Eko turizm doğayı temel alırken sürdürülebilir turizm ekonomik ve sosyal yanlarıyla faydalanılan kaynakların kullanımının bugün ve geleceğe bilinç temelli olarak aktarılması konusunda önemli rol almaktadır. Bu anlamda zeytinyağı turizminin sürdürülebilir turizm ve çevre ile doğrudan bir ilişkisi var olmaktadır ve zeytinyağı turizmi sürdürülebilir turizmin önemli aktivitelerinden biri olarak Türkiye'de de kendini göstermeye başlamıştır (Gülhan, 2016). Sonuç olarak zeytin ve zeytinyağının turizm kapsamında ele alındığında sürdürülebilir turizmin savunduğu ekolojik çevre ve yaşamsal odaklı sistemlerin korunması ve geliştirilmesi ile sürdürülebilirliğe hizmet etmesi de gereklidir. Bu sayede korunan ve geliştirilen bir kaynak olan zeytin ve zeytinyağı gelecek kuşakların da hizmetine sunulabilecektir.

Ayrıca zeytin ve zeytinyağı geleneksel yemek kültürünün bir parçası olarak slow food (yavaş yemek) hareketinin içinde yer almaktadır (Hocaoğlu, 2012). UNESCO'nun belirlediği ilkeler doğrultusunda somut olmayan kültürel miras kategorisinde zeytin yetiştiriciliği ile zeytinyağı kültürü insanlığın ortak mirası olarak aday konumundadır. Zeytin, UNESCO "İnsanlığın Somut OImayan Kültürel Mirasının Temsili Listesi”ne çok uluslu kültür mirası olarak kaydettirilmesi Kültür ve Turizm Bakanlığı çalışmalarında öncelikli hedef olarak yer almaktadır (Ktb, 2017). Sadece tarım ürünü olan zeytin ve zeytinyağı değil aynı zamanda bu turizm faaliyetinde üretim aşamalarının gerçekleştiği zeytin işlikleri, fabrikalar, yağhaneler, kullanılan aletler mimari bir kazanım olarak ve o zamanın kent dokusunu ve endüstriyel üretimini temsil etmesi açısından endüstriyel miras olarak endüstriyel turizmdeki yerini almaktadır.

\subsection{Dünyada Öne Çıkan Zeytinyağı Destinasyonları ve Uygulamaları}

Akdeniz bölgesinde yer alan çoğu ülkede zeytin yetişmektedir. İspanya zeytin ve zeytinyağı üreticisi olarak önde gelen ülkelerinden biri konumundadır. Yaklaşık 1,297841 ton yani dünyadaki üretimin \%60'ını temsil eden zeytinyağını üretmektedir (Millán vd., 2014). Zeytin üretiminde önde gelen diğer ülkeler ise İtalya, Yunanistan ve Türkiye'dir (World Atlas, 2017). Zeytin üretiminde 2017 yılının ilk 10 ülkesi Tablo 1'de yer almaktadır. 
Tablo 1: Zeytin Üretiminde Önde Gelen Ülkeler

\begin{tabular}{ccc}
\hline Sıralama & Ülke & Metrik Ton Yıllık Zeytin Üretimi \\
\hline \hline $\mathbf{1 .}$ & İspanya & $5,276,899$ \\
$\mathbf{2 .}$ & İtalya & $3,220,674$ \\
$\mathbf{3 .}$ & Yunanistan & $2,232,412$ \\
$\mathbf{4 .}$ & Türkiye & $\mathbf{1 , 2 9 2 , 0 7 2}$ \\
$\mathbf{5 .}$ & Tunus & $\mathbf{8 4 1 , 5 2 4}$ \\
$\mathbf{6 .}$ & Fas & 745,019 \\
$\mathbf{7 .}$ & Suriye & 730,692 \\
$\mathbf{8 .}$ & Mısır & 332,321 \\
$\mathbf{9 .}$ & Portekiz & 325,938 \\
$\mathbf{1 0 .}$ & Arnavutluk & 299,404 \\
\hline
\end{tabular}

Kaynak: World Atlas (2017).

Zeytin ve zeytinyağı destinasyonlarına bakıldığında genelde Akdeniz bölgesindeki ülkeler lider konumdadır. Söz konusu ülkeler artık zeytin kültürünü sadece tarımsal olarak sınırlamayarak daha sofistike bir yaklaşımla turizm ile bütünleşen müzeler ve rotalar sunmaktadırlar ve zeytinyağı kültürünü tanıtan web siteleri oluşturarak zeytinyağı turizm tanıtım stratejileri uygulamaktadırlar. Yerel yönetimler zeytinin yetiştiği topraklarını otantik atmosfer ile turizm aktivitelerine dahil etmektedir. Söz konusu rota ve müzelerin bazıları Tablo 2'de yer almaktadır.

Tablo 2: Dünya Genelinde Zeytinyağı Turizmi Rotaları ve Müzeleri

\begin{tabular}{|c|c|c|}
\hline Ülke & Web Sitesi & İsmi \\
\hline İspanya & www.museoaceite.com & MÜZE - Museo del Olivo y del Aceite (Baena) \\
\hline İspanya & www.molienda.com/museo.html & MÜZE - Museo etnográfico de Benalauria \\
\hline İspanya & www.oliva.net & $\begin{array}{l}\text { MÜZE- Museo Activo del Aceite de Oliva y de la } \\
\text { Sostenibilidad de Geolit }\end{array}$ \\
\hline İspanya & $\begin{array}{l}\text { www.artesanosdelamaderadeolivo.com } \\
\text { www.oleohispana.com/museo/fotosalm.htm }\end{array}$ & SANAT EVI-ATÖLYE- Castro del Rio \\
\hline İspanya & http://www.hecoliva.com/principal.htm & MÜZE- Museo Hecoliva \\
\hline İspanya & www.lagardelmudo.com & MÜZE- Museo Lagar del Mudo \\
\hline İspanya & www.pco.es & $\begin{array}{l}\text { MÜZE- Fundación Patrimonio Comunal Oliva- } \\
\text { rero }\end{array}$ \\
\hline İtalya & www.museodellolivo.com & MÜZE-Museo dell' Olivo - Fratelli Carli \\
\hline İtalya & www.museum.it & $\begin{array}{l}\text { MÜZE- Musée de l'Huile d'Olive - Huilerie Ci- } \\
\text { sano del Garda }\end{array}$ \\
\hline İtalya & www.protrevi.com/protrevi/musolivo.asp & MÜZE- Musée de la Civilisation de l'Olivier \\
\hline İtalya & www.lungarotti.it & $\begin{array}{l}\text { MÜZE- Musée de l'Olivier et de l'Huile - Fonda- } \\
\text { tion Lungarotti }\end{array}$ \\
\hline İsrail & www.routedesoliviers-israel.com & ROTA-The Routes of the Olive Tree \\
\hline Türkiye & www.adatepe.com & MüZE- Musée de l'Huile d'Olive d'Adatepe \\
\hline Türkiye & http://www.egea.com.tr/MUZE,DP-7.html & MÜZE-EGEA Olive Oil Museum \\
\hline Yunanistan & www.olivetreeroute.gr & $\begin{array}{l}\text { Euromediterranean Foundation "The Routes of } \\
\text { the Olive Tree" }\end{array}$ \\
\hline Yunanistan & www.piop.gr & $\begin{array}{l}\text { MÜZE-Musée de l'Huile industrielle de Lesbos- } \\
\text { Mytilène (MBEL) }\end{array}$ \\
\hline Fransa & www.ecomusee-olivier.com & MÜZE-Ecomusée de l'Olivier \\
\hline Fransa & www.mucem.org & $\begin{array}{l}\text { MÜZE-Musée des Civilisations de l'Europe et de } \\
\text { la Méditerranée - MuCEM }\end{array}$ \\
\hline
\end{tabular}

Kaynak: International Olive Council, 2018 
Zeytin yetiştirme bölgelerinde sadece zeytin arazilerinin yer alması yeterli değildir; turizmi geliştirmek için bir dizi strateji (tanıtım, işbirliği, yatırım, vb.) olanakları sağlamak, turizmde yer alacak yerel nüfusun özverisini arttırmak, yapılan yatırımlara izin vermek, bölgenin çevresini bir turistik cazibe merkezi haline getirmek ve istikrarlı, sürdürülebilir kalkınmayı teşvik etmek büyük bir önem arz etmektedir (Millán vd. 2014). Tablo 3'te zeytinyağı turizmi tanıtım sitelerinin bazıları yer almaktadır.

Tablo 3: Dünya Genelinde Zeytinyağı Turizmi Ürün ve Tanıtım Siteleri

\begin{tabular}{lll}
\hline \multicolumn{1}{c}{ Ülke } & \multicolumn{1}{c}{ Web Sitesi } & \multicolumn{1}{c}{ İçerik } \\
\hline \hline $\begin{array}{l}\text { Yunanistan } \\
\text { İspanya }\end{array}$ & www.greeking.me & Olive Oil Tasting \& farm tour \\
İspanya & www.andalucia.com & Olive Oil Factories and Tours \\
İspanya & oliveoiltour.com & Olive Oil Tour in Granada \\
İspanya & www.cordobaturismo.es & Touristic Routes Olive Oil \\
İspanya & www.spain.info & Olive oil routes \\
İstirya Adası & www.istria-gourmet.com & $\begin{array}{l}\text { Pure ecological olive exprerience- Olive oil tasting in } \\
\text { the olive groves land }\end{array}$ \\
İtalya & www.visittuscany.com & Istrian Olive oils \\
İtalya & www.discoverypuglia.com & Take a tour of the olive oil producing towns- Wine \\
İtalya & and Olive Oil Roads \\
Fransa & nicetourisme.com & The Olive Oil Route blank \\
Portekiz & uk.visitportoandnorth.travel & The olive oil route in Sabina, Rieti \\
\hline
\end{tabular}

Kaynak: Yazarlar tarafından oluşturulmuştur.

Zeytinyağı turizmi kapsamında hem üretim anlamında hem de zeytinyağı turizmi rotaları, müzeleri ve tanıtım bakımından İtalya ve İspanya'nın bu alana öncülük eden iki ülke olduğu görülmektedir. Başta bu ülkeler olmak üzere dünya genelinde zeytinyağı turizmi ile ilgili turistik aktiviteler düzenlenmektedir. Bu kapsamda dünya genelinde düzenlenen ve düzenlenebilecek zeytinyağı turistik aktiviteleri Tablo 4'te yer almaktadır.

Tablo 4: Zeytinyağı Turizminde Turistik Aktiviteler

\begin{tabular}{lll}
\hline Kırsal-Sportif Aktiviteler & Gastronomik Aktiviteler & $\begin{array}{l}\text { Tarihi-Kültürel Sanatsal Aktivi- } \\
\text { teler }\end{array}$ \\
\hline \hline $\begin{array}{l}\text { Zeytin Tarlalarında Zeytin Toplama } \\
\text { Zeytinyağı Rotaları }\end{array}$ & Tadım Atölyeleri \\
Hasat Şenlikleri & Koklama Atölyeleri & Zeytinyağı Müzesi Ziyaretleri \\
Zeytin Ağaçları ile Trekking Turları & Zeytinyağlı Yemek Turları & Zeytin ve Zeytinyağı Sergileri \\
Yoga & Zeytin Yapım Atölyeleri & Zeytinyağı Fuarlarına Katılım \\
Zeytin Toplama Yarışması & & Tarihi Zeytinyağı Fabrikaları ve \\
Zeytinyağı ile Vücut Terapi Masajları ve Maske & & İşliklerine Ziyaret \\
\hline
\end{tabular}

Kaynak: Yazarlar tarafından oluşturulmuştur.

Zeytin ve zeytinyağının sunduğu kaynaklar bu açıdan ülkelere ve bölgelere kültürel, coğrafik, tarımsal ve turistik gelişim için temel oluşturmaktadır. Çok işlevli bir tarımsal ürün olarak kırsal bölgelere ekonomik ve sosyal canlılık katabilmektedir. 


\subsection{Bodrum Yarımadası}

Zeytincilik, Türkiye'de Doğu Anadolu ve iç Anadolu Bölgeleri dışındaki tüm bölgelerde yapılabilmektedir. Muğla'nın da merkezi dâhil çiftçilik yapan bütün köylerinde zeytincilik geçmişten bugüne yapılmaktadır. Muğla ili dahilindeki Bodrum başta olmak üzere Seydikemer, Fethiye, Dalaman, Ortaca, Köyceğiz, Datça, Marmaris, Ula, Kavaklıdere, Menteşe, Yatağan ve Milas ilçelerinde; geçen yıl ile karşılaştırıldığında; 2016-2017 üretim sezonunda Kavaklıdere ve Köyceğiz dışındaki tüm ilçelerin zeytin ve zeytinyağı rekoltesinde artış olacağı tahmin edilmiştir. Muğla ili genelinde meyve veren 16.283.743 adet, meyve vermeyen 1.301 .742 adet zeytin ağacı olduğu; ağaç başına ortalama 7,0 kg zeytin hesabıyla toplam 119.686 ton zeytin danesi elde edileceği, bunun 11.111 ton'un yemekliğe, 108.575 ton'un yağlığa ayrılacağı, ortalama 5,5 randıman ile 19.312 ton zeytinyağı elde edileceği öngörülmüştür (UZZK, 2016: 22-23). Sayısal verilerin Bodrum yarımadası ve çevresinde zeytin ve zeytinyağı rekoltesinde verimliliğin arttığını ve zeytinyağı turizmi açısından elverişli olduğunu gösterdiği söylenebilir. Ayrıca köklü bir tarihe ve zengin coğrafyaya sahip olan Bodrum yarımadası birçok turizm çeşidine olanak sağlayarak yerli ve yabancı çok sayıda ziyaretçiyi ağırlamaktadır.

Tablo 5: Milas - Bodrum Havalimanı Yolcu Istatistikleri - Yıllara Göre (Milyon)

\begin{tabular}{cccccccccccc}
\hline Yıllar & $\mathbf{2 0 0 7}$ & $\mathbf{2 0 0 8}$ & $\mathbf{2 0 0 9}$ & $\mathbf{2 0 1 0}$ & $\mathbf{2 0 1 1}$ & $\mathbf{2 0 1 2}$ & $\mathbf{2 0 1 3}$ & $\mathbf{2 0 1 4}$ & $\mathbf{2 0 1 5}$ & $\mathbf{2 0 1 6}$ & $\mathbf{2 0 1 7}$ \\
\hline \hline İç Hatlar & 0.82 & 0,84 & 0,97 & 1,16 & 1,39 & 1,61 & 1,74 & 1,94 & 2,3 & 2,3 & 2,5 \\
Dış Hatlar & 1,75 & 1,90 & 1,81 & 1,91 & 1,99 & 1,91 & 1,89 & 1,83 & 1,6 & 0,9 & 1 \\
\hline \hline Toplam & $\mathbf{2 , 5 7}$ & $\mathbf{2 , 7 4}$ & $\mathbf{2 , 7 8}$ & $\mathbf{3 , 0 7}$ & $\mathbf{3 , 3 8}$ & $\mathbf{3 , 5 2}$ & $\mathbf{3 , 6 3}$ & $\mathbf{3 , 7 7}$ & $\mathbf{3 , 9}$ & $\mathbf{3 , 2}$ & $\mathbf{3 , 5}$ \\
\hline
\end{tabular}

Kaynak: Milas-Bodrum Havaalanı (2017).

Tablo 5'te yer alan Tav Havalimanları Milas- Bodrum Havalimanı yolcu istatistiklerinden de anlaşıldığı üzere varan yolcu sayısı bazı yıllar yaşanan krizlerden dolayı azalma gösterse de her geçen yıl artış göstermektedir. Bu anlamda Bodrum ulusal ve uluslararası ziyaretçi bakımından önemli bir turizm destinasyonu konumundadır

\section{Araştırmanın Yöntemi}

Araştırmada katılımcıların Bodrum yarımadasında zeytinyağı turizminin uygulanabilirliğine ilişkin algılarını ve düşüncelerini ortaya koymaları açısından nitel araştırma yöntemlerinden olgubilim yöntemi kullanılmıştır. Bu yöntemde araştırmacı katılımcının kişisel (öznel) deneyimleri ile ilgilenmekte, bireyin algılamaları ve olaylara yükledikleri anlamları incelemektedir (Yanık, 2015). Olgular yaşadığımız dünyada olaylar, deneyimler, algılar, yönelimler, kavramlar ve durumlar gibi çeşitli biçimlerde karşımıza çıkabilmektedir (Yıldırım ve Şimşek, 2008). Araştırmanın örneklemi olasılık dışı örnekleme türlerinden amaçlı örnekleme yöntemine göre belirlenmiştir. Bu yöntem araştırılan kişi ya da durumları derinlemesine anlama, arasındaki ilişkileri keşfetme ve açıklama olanağı (Büyüköztürk, 2012) sunduğu gibi araştırmacıya da kimlerin seçileceği konusunda kendi yargısını kullanma ve araştırmanın amacına en uygun olanları örnekleme alma imkanı tanıdığı (Balcı, 2005) için kullanılmıştır. Bu kapsamda araştırmanın örneklemini Bodrum yarımadasında yaşayan konu ile ilgili doğrudan veya dolaylı olarak etkisi olan bölge sakini, kamu, STK, üniversite ve turizm işletmelerinin sahipleri yöneticisi veya çalışanı 13 kişi oluşturmaktadır.

Olgubilim araştırmalarında yaşantıların derinliğine ortaya konması ve açıklanması için araştırmacının görüşülen birey ya da bireylerle yoğun bir etkileşim içine girmesi gerekmektedir ve başlıca veri toplama aracı görüşmedir (Yıldırım ve Şimşek, 2008). Araştırmada da veri toplama tekniği olarak, yarı yapılandırılmış sözlü görüşme tekniği kullanıımıştır. Alan araştırması, 2018 yılı Ocak ayı ile Şubat ayı arasında, ilgili paydaşlarla yüz yüze görüşülerek gerçekleştirilmiştir. 
Görüşme sırasında dile getirilen verilerin kaybolmasını engellemek için görüşmecilerin izni alınarak ses kayıt cihazı ve araştırmacı notları kullanılmıştır. Katılımcılar ve görüşmelerle ilgili detaylı bilgiler tablo 6 ve 7'de yer almaktadır.

Tablo 6: Katılımcılara Ait Bilgiler

\begin{tabular}{|c|c|c|c|c|}
\hline Kod No & Yaş & Cinsiyet & Eğitim Durumu & Görevi / Unvanı \\
\hline K (1) & 48 & K & Lise & $\begin{array}{l}\text { Yerel Gazete Sahibi, Restoran İşletmecisi, Bodrum Ya- } \\
\text { rımadası Yerlisi ve Zeytin Arazileri Sahibi }\end{array}$ \\
\hline$K(2)$ & 45 & K & Yüksek Lisans & Dernek Yöneticisi \\
\hline $\mathrm{K}(3)$ & 60 & K & Lise & STK Yöneticisi ve Bodrum Sakini \\
\hline $\mathrm{K}(4)$ & 27 & K & Lisans & STK Üyesi \\
\hline $\mathrm{K}(5)$ & 38 & E & Lisans & $\begin{array}{l}\text { Turizm İşletme Sahibi ve Yöneticisi, Profesyonel Tu- } \\
\text { rizmci }\end{array}$ \\
\hline$K(6)$ & 50 & $\mathrm{E}$ & Lise & $\begin{array}{l}\text { Muğla'nın Yerlisi, Yerel Zeytin Üreticisi ve Pazarlama- } \\
\text { cısı }\end{array}$ \\
\hline $\mathrm{K}(7)$ & 58 & K & Lise & Bodrum Kent Konseyi Üyesi ve STK Başkanı \\
\hline $\mathrm{K}(8)$ & 37 & $\mathrm{E}$ & Ön lisans & Turizm İşletme Yöneticisi \\
\hline K (9) & 32 & K & Lisans & Yiyecek İçecek İşletme Yöneticisi \\
\hline K (10) & 31 & K & Yüksek Lisans & Profesyonel Turist Rehberi, Bodrum Sakini \\
\hline $\mathrm{K}(11)$ & 44 & $E$ & Doktora & Akademisyen \\
\hline $\mathrm{K}(12)$ & 46 & $E$ & Lisans & Seyahat Acentesi Sahibi ve Yöneticisi \\
\hline $\mathrm{K}(13)$ & 53 & $\mathrm{E}$ & Lisans & Yerel Yönetim Temsilcisi \\
\hline
\end{tabular}

Görüşmeler 10 dakika ile 37 dakika arasında farklı sürelerde gerçekleştirilmiştir. Görüşme süreleri arasında oluşan bu farkın, görüşmecilerin konu ile ilgili bilgi ve ilgi düzeyinden dolayı oluştuğu söylenebilir. Toplam 13 kişi ile 250 dakika 41 saniye görüşme gerçekleştirilmiştir. Görüşmeler ortalama 19 dakika sürmüştür. Görüşmeler kişilerin kurumlarında yapılmıştır. Katılımcılar için isim ve kurum belirtilmeksizin rastgele K1, K2, K3... şeklinde kod numaraları kullanılmıştır.

Tablo 7: Görüşmelere Ait Bilgiler

\begin{tabular}{ccc}
\hline Görüşülen & Görüşme Tarihi & Görüşme Süresi \\
\hline K (1) & 15.01 .2018 & 18 Dakika 40 Saniye \\
K (2) & 18.01 .2018 & 10 Dakika 10 Saniye \\
K (3) & 18.01 .2018 & 19 Dakika 3 Saniye \\
K (4) & 19.01 .2018 & 11 Dakika 43 Saniye \\
K (5) & 22.01 .2018 & 37 Dakika 55 Saniye \\
K (6) & 23.01 .2018 & 10 Dakika 11 Saniye \\
K (7) & 27.01 .2018 & 15 Dakika 13 Saniye \\
K (8) & 28.01 .2018 & 22 Dakika 25 Saniye \\
K (9) & 1.02 .2018 & 25 Dakika 17 Saniye \\
K (10) & 3.02 .2018 & 12 Dakika 24 Saniye \\
K (11) & 3.02 .2018 & 20 Dakika 20 Saniye \\
K (12) & 5.02 .2018 & 16 Dakika 18 Saniye \\
K (13) & 6.02 .2018 & 32 Dakika 35 Saniye \\
\hline
\end{tabular}

Olgubilim araştırmalarının veri analiz sürecinde katılımcılarla yapılan sözlü görüşmelerden elde edilen verilerin tanımlanıp temaların belirlenmesi gerekmektedir (Yanık, 2015). Bu doğrultuda yarı yapılandırılmış görüşmelerden elde edilen veriler, deşifre edilerek betimsel analiz ve içerik analizi ile çözümlenmiştir. Ortaya çıkan ortak ve benzer ifadeler için temalar oluşturulmuştur. Güçlü yanlar, zayıf yanlar, fırsatlar ve tehditler başlıkları olmak üzere dört ana tema altında toplanmıştır. 


\section{Bulgular}

Bu bölümde araştırma kapsamında yapılan SWOT analizine ilişkin bulgular ana temalar çerçevesinde değerlendirilmiş, alıntılara yer verilmiş ve tablolaştırılmıştır.

Bodrum Yarımadası'nın Zeytinyağı Turizmi Açısından Güçlü Yönleri

Zeytinyağı turizmi açısından katılımcıların görüşleri doğrultusunda Bodrum yarımadasının güçlü yönleri tablo 8'de sınıflandırılmıştır ve bazı katılımcı görüşleri şu şekildedir.

K10 "Bodrum'da zeytin ve zeytinyağı üzerine dernek, grup, kurumlar ve birçok yerel üretici mevcuttur. Sadece bu turizm çeşidine dikkat çekilerek turizmcilerin ve zeytin ailesi ile bağlantılı herkesle bir araya gelinmeli ve en uygun zeytin üretim alanlarından bir harita çıkarılarak proje bazlı olarak sektör ve kamu ile birlikte bu turizm çeşidine başlanmalı ve üretimde de, turizm hizmetinde de Bodrum öncelikle kendi içinde fark yaratmalıdır".

K13 "Bodrum zeytinyağı turizmi için düzenlemeler yapıldığında uygun bir destinasyondur. Bodrum hali hazırda bir turizm alt yapısına sahiptir. Bu anlamda zeytinyağı turizminin başlatılabilmesi için temelde bir organizasyon söz konusudur. Nadir de olsa bazı acenteler zaten bu butik turları kendi bünyelerinde gerçekleştirmektedirler. Bu tarz acenteler bu turizm çeşidine öncülük edebilirler".

Tablo 8: Bodrum Yarımadasının Zeytinyağı Turizmi Açısından Güçlü Yönleri

\begin{tabular}{l}
\hline Güçlü Yönler \\
\hline \hline Hali hazırda zengin bir turizm potansiyeline sahip olması \\
Tarihi bakımdan zengin bir geçmişe sahip olması \\
Coğrafi konumu bakımından doğal güzelliklere sahip olması \\
Zeytinyağı turizmi oluşturulması için uygun alanlara sahip olması \\
Zeytinyağı turizmi rotalarının oluşturulması açısından uygun olması \\
Doğa yürüyüşleri, dağcılık ve diğer doğa aktiviteleri için uygun parkurların ve Karia yolunun bulunması \\
Yerel halkın turizm faaliyetlerine aşina olması \\
Sivil toplum örgütlerinin, doğa gönüllülerinin ve çok çeşitli spor aktiveleri için özel kurumların ve derneklerin bulun- \\
ması \\
Bodrum Yarımadasına ulusal ve uluslar arası ulaşımın deniz, kara ve havayolu ile sağlanabilmesi \\
Farklı turizm türleri ile entegre edilebilme potansiyelinin bulunması \\
Hali hazırda bir pazarın varlığı ve turizm alt yapısına sahip olması
\end{tabular}

K7 "Bodrum zaten turizmde uluslararası bir düzeyde. Bu turizm çeşidi ile daha fazla dikkat çekici hale getirilebilir. Sadece eğlence mekanları ile değil, gıda ürünleri ile de tanıtılabilir. Zeytin festivali yapılabilir, en kaliteli zeytinyağı yarışması yapılabilir, zeytini, zeytinyağını en iyi kim tanıtıyor bununla ilgili teşvik edici yarışmalar yapılıp ödüller verilebilir. Kozmetikte, tıpta zeytinyağı, zeytin nerede bununla ilgili Ar-Ge çalışmaları yapılabilir. Bunu dünya ülkeleri yaparken biz neden yapmayalım ki. Bodrum bilinen bir yer ve bu bir fırsata çevrilebilir böyle bir turizm şekli ile ve zeytinle birlikte anılabilir. Ulaşım olanaklarına sahip ve Avrupa ile ulaşım sorunu yok".

K12 "Turizme değer katmak ülke ekonomisine de değer katmak anlamına gelir ve toprağa bu şekilde sahip çıkabiliriz, Bodrum'daki turizm sezonunu da zeytinyağı turizmi başta olmak üzere farklı turizm çeşitleri ile entegre edebiliriz. Ayrıca zeytinyağı turizminin yanısıra, mandalina turizmi, şarap turizmi, yerel ot turizmi... ve buna benzer bir çok turizm çeşidi ve yöreye ait değerler için rotalar oluşturmaya elverişlidir". 


\section{Bodrum Yarımadasının Zeytinyağı Turizmi Açısından Zayıf Yönleri}

Katılımcıların zeytinyağı turizmi açısından Bodrum yarımadasının zayıf gördükleri yönleri ve bu konu ile ilgili bazı dikkat çekici görüşleri aşağıda yer almaktadır.

K3 "Biz artık çevreyi koruyamıyoruz. Eski su kuyularını, kümbetleri, sarnıçları koruyarak eski sulama sistemleri ile belki de tarımsal alanlar sulanmalı fakat geç kalınmış. Köylü ekonomik olarak zorlu çekmektedir, çünkü çok fazla emek var, toplanması çok zor zeytinin ve çok az kazanıyorlar dolayısıyla yatırımlarını farklı yapıyorlar, kendi topraklarını satıyorlar ve bu sebeplerden dolayı şuan kentten köye göç söz konusudur ve bu turizm şekli ile bu durum değerlendirilebilir.

Tablo 9: Bodrum Yarımadasının Zeytinyağı Turizmi Açısından Zayıf Yönleri

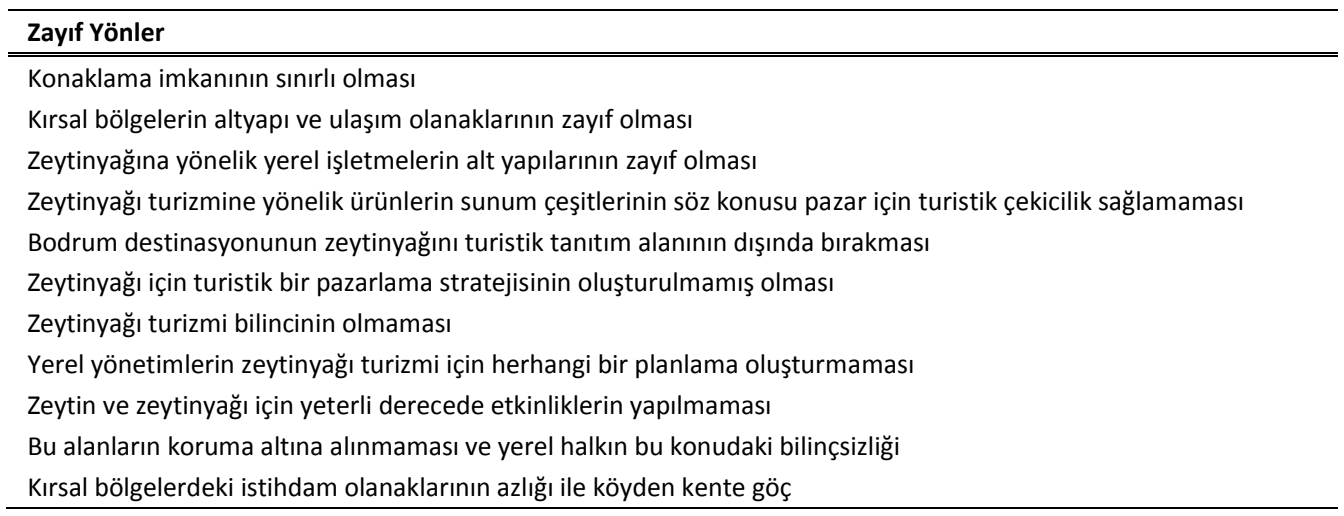

K5 "Zeytin hasatına gittiğimizde veya yağhaneye gittiğimizde orada küçümsenmeyecek alışverişler oluyor. Ülkelerine, şehirlerine kargolarla zeytinyağı sabunundan hediyelik zeytinyağı ile ilgili ürünlere kadar gönderiliyor. Bodrum'da bu potansiyel git gide artıyor. Bu potansiyelin artması üretim kalitesini arttırır, yaşam kalitesini arttırır. Kırsal alanlardan göç olmaz. Yaşam kalitesi artar. Şimdi göç fazla. Zeytinliklerde zeytinler yerlerde. Göç olduğu için zeytinliklerle ilgilenenler azalıyor.

K6 "Bodrum'daki zeytinlikler eskisi gibi bakımlı değil artık. Bodrum'da zeytinlik var, zeytin var ama bakımlı değil. Kendi haline bırakılmış durumda.

K7 "Turizm açısından baktığımızda çalışmalarda Bodrum'daki çalışmalarda vizyon eksikliği var. Fuarlara gidiliyor ve sadece Bodrum'un otellerini tanıtıyorlar. Neden bu yönü ile de tanıtılmıyor? Bu sorgulanmalı diye düşünüyorum.

Bodrum Yarımadasının Zeytinyağı Turizmi Açısından Fırsatları

Zeytinyağı turizmi açısından Bodrum yarımadasının fırsatları tablo 10'da yer almaktadır. Ayrıca bazı katılımcı görüşleri de şu şekildedir.

K8 "Zeytinyağı turizminin başlamasıyla zeytinlikler daha fazla değer kazanıp daha farkındalıklı bir biçimde koruma altına alınacaktır. Üretim kalitesi artacak turistik bir hizmete dönüştüğü için ulusaldan uluslararası bir marka haline getirilebilecektir.

K2 "Turistler yerinde yöre kültürü ve zeytinyağı hakkında bilgi ediniyorlar. Bu tür faaliyetlerin bölge tanıtımına ve yerel ekonomiye katkı sağlayacağını düşünüyorum.

K1 "Zeytin ağacı geleceğe yatırım, gelecek nesillere kök bırakan bir kültürdür. Bu turizm şeklinin yapılmaması için hiçbir engel yok. Buna göre zeytin yetiştiriciliği ve turizmi yapılabilir. 
Tablo 10: Bodrum Yarımadasının Zeytinyağı Turizmi Açısından Fırsatları

\begin{tabular}{l}
\hline SWOT Analizi: Fırsatlar \\
\hline \hline Sertifikalı gastronomik ürünlerin artması ve zeytinyağı ve zeytin ürünlerinin markalaşması \\
Yerel halka ek bir istihdam sağlanması ve göçün engellenmesi \\
Çevre bilincinin artması ve bu alanların tescillenmesi \\
Döviz kazancının artması \\
Ulusal ve uluslararası alanda yeni bir tanıtım aracı olması \\
Kırsal alanlarda ulaşım ve altyapı olanaklarının gelişmesi \\
Alternatif gelir kaynağı oluşturması \\
Kültürel, endüstriyel miras ve tarihi yapıların korunması
\end{tabular}

K13 "Farklı turizm türlerinin uygulamaya sokulması hem yerel hem de ulusal anlamda birçok katkı sunabilir. Zeytinyağı turizmi ile de o bölgede yaşayan halka maddi anlamda destek sağlayabilir, çalışma fırsatı sunar oradaki halka, dolayısı ile insanlar geçinebilmek için başka yerlere gitmek zorunda kalmaz".

K11 "Ulusal ve uluslararası anlamda, ülkenin tanıtımında, imaj oluşumunda, ürünlerin markalaşmasında, rekabet gücünün artırılmasında ve diğer gastronomik ürünlerinde tanıtılmasında iyi bir fırsat sunabilir bu turizm türü.

K14 "Zeytinyağı turizminin başlamasıyla zeytinlikler daha fazla değer kazanıp daha farkındalıklı bir biçimde koruma altına alınacaktır. Üretim kalitesi artacak turistik bir hizmete dönüştüğü için ulusaldan uluslar arası bir marka haline getirilebilecektir.

K10 "Kırsal alanlara ulaşım ve ne yazık ki alt yapı, sulama vb. problemlere de bu turizm çeşidi ile dikkat çekilebilir. Turizmin gerçekleşmesi için alt yapının ve ulaşımın büyük bir engel olduğu unutulmamalıdır.

\section{Bodrum Yarımadasının Zeytinyağı Turizmi Açısından Tehditleri}

Zeytinyağı turizmi açısından Bodrum yarımadasının tehditleri Tablo 11'de yer almaktadır. Ayrıca bazı katılımcı görüşleri de şu şekildedir.

K14 "Zeytinyağı turizmi evet olabilirliği mümkündür, ancak bu süreci tüm yıla yaymak nasıl gerçekleşecektir. Çünkü zeytinin de belli bir dönemi var ve o dönem bittiğinde bu turizm türü de sonlanacaktır.

Tablo 11: Bodrum Yarımadasının Zeytinyağı Turizmi Açısından Tehditleri

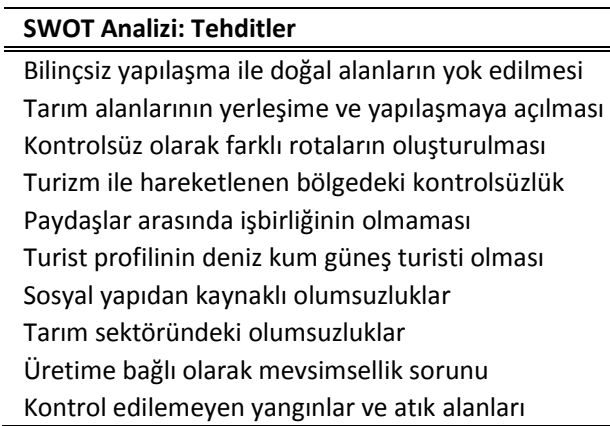

K9 "Bodruma gelen turistler genellikle deniz, eğlence güneş için geliyor, bu turistleri zeytinyağı turizmi ile buluşturmak nasıl olacak, ancak bu ürüne ilgisi olması gerekir yoksa amaç eğlence çoğu turist için. Ayrıca zamanla kırsal alanlarda yapılar inşa edilmeye başlayacaktır haliyle, sonucunda bina yığınları ve yeşilliklerin zarar görme riski de bulunmaktadır. 


\section{Sonuç ve Öneriler}

Son yıllarda gittikçe popüler hale gelen gastronomi turizminin artan öneminden dolayı, zeytinyağı turizmi gelişimine potansiyel bir bağlılık söz konusudur (López-Guzmán, Cañero Morales, Cuadra ve Orgaz-Agüera, 2016). Zeytinyağı turizmi tüm tanımlayıcı özelliklere sahip olduğundan sürdürülebilir gastronomi turizminin bir ifadesidir (Millán, Romero ve Rivas, 2018). Hızla popüler hale gelen bu turizm türüne Akdeniz ülkeleri liderlik etmektedir. Çünkü Akdeniz ülkeleri dünyanın en iyi zeytinyağı üreticileridir ve zeytinyağı üretimi, Akdeniz ülkelerindeki en önemli tarımsal faaliyetlerden biridir (López-Guzmán vd., 2016). Zeytinyağı turizmi kapsamında hem üretim anlamında hem de zeytinyağı turizmi rotaları, müzeleri ve tanıtım bakımından İtalya ve İspanya'nın bu alana öncülük eden iki ülke olduğu görülmektedir. Başta bu ülkeler olmak üzere dünya genelinde birçok ülke zeytinyağı turizmi ile ilgili turistik aktiviteler düzenlenmektedir. Söz konusu ülkeler artık zeytin kültürünü sadece tarımsal olarak sınırlamayarak daha sofistike bir yaklaşımla turizm ile bütünleştiren müzeler ve rotalar sunmaktadır ve zeytinyağı kültürünü tanıtan web siteleri oluşturarak zeytinyağı turizm tanıtım stratejileri uygulamaktadır. Diğer taraftan yerel yönetimler zeytinin yetiştiği topraklarını otantik atmosfer ile turizm aktivitelerine dahil etmektedir. Sayısal veriler Akdeniz ülkesi olan Türkiye'nin zeytin ve zeytinyağı üretiminde dünyanın önde gelen ülkeleri arasında olduğunu göstermektedir. Ancak zeytinyağı turizmi konusunda diğer Akdeniz ülkeleri ile karşılaştırıldığında bu turizm türünden faydalanılamadığı görülmektedir. Bu doğrultuda araştırmada zeytin ve zeytinyağı anlamında oldukça zengin ve popüler bir turizm bölgesi olan Bodrum yarımadasında zeytinyağı turizminin uygulanabilirliği SWOT analizi yöntemi ile değerlendirilmiştir.

SWOT analizi neticesinde elde edilen veriler, zeytinyağı turizmi için bölgeyi tehdit eden ve bölgenin zayıf yönlerinin olduğunu gösterse de doğru uygulamalar sonucu zeytinyağı turizminin Bodrum yarımadası için uygun bir turizm etkinliği olabileceğini ortaya koymaktadır. Analiz doğrultusunda bu turizm türünün uygulanabilirliğini daha gerçekçi hale dönüştürebilmek için geliştirilen öneriler şu şekildedir.

$>$ Yöre halkı zeytinyağı turizmi konusunda bilinçlendirilmelidir.

$>$ Turizm sektörünün ve yerel yönetimlerin iş birliği sağlaması gerekmektedir.

> Üretim atölyeleri turizm faaliyetlerine uygun hale getirilmeli ve ürünler pazara uygun turistik çekimi arttıracak şekilde üretilmelidir ve kalite yükseltilmelidir.

$>$ Söz konusu alanlara yönelik teşvik, hibe sağlanmalı ve bu alanları korumak için öncelikle duyarlıık arttırılmalıdır.

$>$ Yerel yönetimlerin ulusal ve uluslararası tanıtım için zeytinyağı turizmine özel web siteleri oluşturması ve sosyal ağları yayması gerekmektedir.

$>$ Yöresel ürünlerin tanıtımı için broşür, afiş gibi tanıtım araçları basılmalı fuar, şenlik vb. organizasyonlar arttırılmalıdır.

$>$ Ulusal ve uluslararası gastronomi fuarlarına yönelik çalışmalar yapılmalıdır.

> Eski üretim atölyelerinin, değirmenlerin, geleneksel üretim araçlarının restorasyonu ve tamiratı yapılmalıdır.

> Yerel üreticilerin zeytinyağı turizmini gerçekleştirmesi için eğitimler düzenlenmeli ve deneyimli turizm personelleri istihdam edilmelidir.

Zeytinyağı turizmi Bodrum Yarımadası'nın turizm potansiyeli ile birlikte ele alındığında alternatif bir turizm çeşidi olarak destinasyonun güçlenmesine, rekabet gücünün artmasına, sürdürülebilirliğine ve kırsal bölgelerinin kalkınmasına katkı sağlayacağı düşünülmektedir. Bundan sonraki araştırmalar da yerli ve yabancı turistlerin bu turizm türü ile ilgili davranışları ölçülebilir. Yapılacak olan çalışmalar konunun güncel tutulması ve bu turizm türünün gerçekleştirilmesi açısından önem taşımaktadır. 


\section{Kaynaklar}

Agüera, Francisco Orgaz; Cuadra, Salvador Moral; López-Guzmán, Tomas; Morales, Pablo Canero (2017), “Estudio De La Demanda Existente En Torno Al Oleoturismo. El Caso De Andalucía", Cuadernos De Turismo, Vol. 39: 437-453.

Băltescu, Codruta Adina (2016), "Culinary Experiences as A Key Tourism Attraction. Case Study: Braşov County", Bulletin of the Transilvania University of Braşov Series V: Economic Sciences. Vol. 9 No. 58: 107-112.

Balcı, Ali (2005), Sosyal Bilimlerde Araştırma, 5. Baskı, Ankara: Pegem A Yayıncılık.

Boyne, Steven; Hall, Derek; Williams, Fiona (2003), "Policy, Support and Promotion for Food-Related Tourism İnitiatives: A Marketing Approach to Regional Development", Journal of Travel \& Tourism Marketing, Vol. 14 No. 3-4: 131-154.

Büyüköztürk, Şener; Kılıç Çakmak, Ebru; Erkan Akgün, Özcan; Karadeniz, Şirin; Demirel, Funda (2012), Bilimsel Araştırma Yöntemleri, 11. Baskı, Ankara: Pegem Akademi.

Campón-Cerro, Ana Maria; Folgado-Fernández, Jose Antonio; Hernández-Mogollón, Jose Manuel (2017), “Rural Destination Development Based on Olive Oil Tourism: The Impact of Residents' Community Attachment and Quality of Life on Their Support for Tourism Development", Sustainability, Vol. 9 No. 9: 1624.

Cañero Morales, Pablo M; López-Guzmán Guzmán, Tomas J; Moral Cuadra, Salvador; Agüera, Francisco Orgaz (2015), “Análisis De La Demanda Del Oleoturismo En Andalucía”, Revista de Estudios Regionales, No. 104: 133-149.

Drašković, Slavka (2016), “Gastronomy And Tourism Destination Competitiveness”, Quality As A Basis For Tourism Destination Competitiveness, Sitcon, 150-154.

Erdoğan, Nazmiye (2003), Çevre ve (Eko) Turizm- Turizm Illkeleri, 1. Baskı, Ankara: Erk Yayıncılık.

Gülhan, Demet (2016), "Sürdürülebilir Turizm Kapsamında Tarım Endüstrisi ve Zeytinyağı Turizminin Birgi Yerleşiminde Olabilirliği Üzerine Bir Değerlendirme", Social Sciences, C. 11, S. 2: 116-132.

Hocaoğlu, Dilek (2010), “Kültürel Miras Olarak Yemek Kültürü: Cittàslow Seferihisar'ın Yavaş Yemekleri”, 2nd Conference of the Agrindustrial Design, 26-28 Nisan, İzmir Ekonomi Üniversitesi, İzmir, Turkey.

International Olive Oil Organisation (2017), “Olive Museums \& Routes”, http://www.internationaloliveoil.org, (Erişim: 21.11.2017).

Kaufmann, Hans Ruediger; Orphnidou, Yianna; Granau, Werner (2012), “Agrifood Meet Agritourism: Outlining A New Trend in Cypriot Tourism Industry. (Ed. Kagermeier, Andreas; Saarinen, Jarkko), Transforming and Managing Destinations: Tourism and in A Time Of Global Risk, Mannheim.

Kültür ve Turizm Bakanlığı (2017), "Basın- Geleneksel Zeytin ve Zeytinyağı Kültürü İnsanlığın Ortak Mirası Olma Yolunda”, http://basin.kulturturizm.gov.tr/TR,191382/geleneksel-zeytin-ve-zeytinyagi-kulturu-insanligin-orta-.html, (Erişim: 20.11.2017).

Lopez-Guzman, Tomas; Hernandez-Mogollon, Jose Manuel; Dı-Clemente, Elide (2014), "Gastronomic Tourısm As An Engıne For Local And Regıonal Development", Regional and Sectoral Economic Studies, Vol.14. No. 1: 95-102.

López-Guzmán, Tomas; Morales, Pablo. Cenero; Cuadra, Salvador Moral; Agüera, Francisco Orgaz (2016), “An Exploratory Study of Olıve Tourısm Consumers", Tourism and Hospitality Management, Vol. 22, No. 1: 57-68.

Milas-Bodrum Havaalanı (2017), "Sayısal Veriler", http://www.milas-bodrumairport.com/tr-TR/havayollari1/Pages/istatistikler.aspx. (Erişim: 20.01.2018).

Millán, Genoveva; Arjona, Juan; Amador, Luis (2014), “A New Market Segment For Olive Oil: Olive Oil Tourism In The South Of Spain”, Agricultural Sciences, Vol. 5, No. 3: 179-185.

Millán, Genoveva; Morales Fernández, Emilio; Agudo Gutiérrez, Eva (2010), “El Oleoturismo Como Motor De Desarrollo Rural: La Denominación De Origen De Montoro-Adamuz", Mundo Agrario, Vol. 11, No. 21.

Millán, Genoveva; Agudo Gutiérrez, Eva; Agudo Gutiérrez, Juan (2010), “Oiltourism In The South-East of Spain: The Necessity of Coordinating The Tourist Activity With The Agrarian One for The Development of The Rural Areas". Panorama Socioeconómico, Vol. 28, No. 41: 116-124.

Millán, Genoveva; María, Pablo Romero; Javier, Sanchez Rivaz (2018), “Oleotourism as a Sustainable Product: An Analysis of Its Demand in the South of Spain (Andalusia)", Sustainability, Vol. 10, No. 101: 1-19.

Pullphothong, Ladapha; Sopha, Chiranut (2013), "Gastronomic tourism in Ayutthaya”, OAP, School of Culinary Art, Suan Dusit Rajabhat University, Bangkok, Thailand.

Saltık, Işıl Arıkan; Çeken, Hüseyin (2017), “Agro Turizmde Yeni Eğilimler: Zeytinyağı Turizmi”, Journal of Economics, C. 89: 102. 


\section{Eskişehir Osmangazi Üniversitesi IïBF Dergisi}

Millán, Genoveva; Arjona-Fuentes, Juan Manuel; Amador Hidalgo, Luis (2017), “Olive Oil Tourism: Promoting Rural Development in Andalusia (Spain)", Tourism Management Perspectives, Vol. 21: 100-108.

Tuik (2017), "Bitkisel Üretim İstatistikleri", http://rapory.tuik.gov.tr/20-11-2017-22:52:445705839203587966241490691435.htm/? , (Erişim:20.11.2017).

UZZK (2016), "2016-2017 Üretim Sezonu Zeytin ve Zeytinyağı Rekoltesi Ulusal Resmi Tespit Heyeti Raporu", http://www.nazillitb.org.tr/Portals/128/dosyalar/TURKIYE_2016-17_REKOLTE_RAPORU.pdf, (Erişim: 05.07.2018).

World Atlas (2017), "Leading Olive Producing Countires", https://www.worldatlas.com/articles/leading-olive-producing-countries.html, (Erişim: 21.11.2017).

Yanık, Akan (2015), Fenomenolojik Araştırma ve Süreçleri, Bilimsel Araştırma Yöntemleri (Kavramlar, Analizler, Araştırmalar), (Ed. Yüksel, Atilla; Yanık, Akan; Ayazlar, Reyhan Arslan), 1.Baskı, Ankara: Seçkin Yayıncılık.

Yıldııım, Ali; Şimşek, Hasan (2008), Sosyal Bilimlerde Nitel Araştırma Yöntemleri, 6.Baskı, Ankara: Seçkin Yayıncılık. 